Prace Filologiczne. Literaturoznawstwo 10(13) 2020

ISSN 2084-6045

e-ISSN 2658-2503

Creative Commons: Uznanie autorstwa 3.0 PL (CC BY)

DOI: $10.32798 /$ pflit.568

\title{
U STÓP POMNIKÓW. KANTATY OKOLICZNOŚCIOWE KU CZCI ADAMA MICKIEWICZA I JULIUSZA SŁOWACKIEGO*
}

\author{
At the Feet of Monuments. \\ Commemorative Cantatas Celebrating Adam Mickiewicz and Juliusz Słowacki
}

\author{
MALGORZATA SOKALSKA \\ Uniwersytet Jagielloński w Krakowie, Polska \\ E-mail: malgorzata.sokalska@uj.edu.pl \\ ORCID: 0000-0002-2896-9468
}

\begin{abstract}
Monuments erected in honour of poets and cantatas dedicated to them are connected by the community dimension of the cult which they manifest. In the monuments erected from the mid-nineteenth century and onwards to commemorate Mickiewicz and Słowacki, we can observe a particular difference in the perception of both poets. The first is presented as a poet-prophet from the very beginning, the second receives such attributes only with time (at the end of the twentieth century). A similar phenomenon can be seen in cantatas' libretti often composed and performed on the occasion of the unveiling of the monuments dedicated to the bards. Compositions in honour of Mickiewicz are quantitatively more numerous and more accurately define his status as a poetprophet, whereas Słowacki is deified in this genre rather as a poet, master of words.
\end{abstract}

Keywords: cantata libretto, commemorative creation, monument, cult of poets

\section{Streszczenie}

Pomniki ku czci wieszczów i dedykowane im kantaty łączy wspólnotowy wymiar kultu, którego są przejawem. Fundowane od połowy XIX wieku pomniki Mickiewicza i Słowackiego pozwalają zauważyć szczególną różnicę w postrzeganiu obu twórców. Pierwszy od początku postaciowany jest jako wieszcz-prorok, drugi dopiero z czasem (pod koniec XX wieku) otrzymuje takie atrybuty. Podobne zjawisko zauważyć można w librettach kantat komponowanych i wykonywanych częstokroć z okazji odsłonięcia pomników dedykowanych wieszczom. Kantaty ku czci Mickiewicza są ilościowo obfitsze i dokładniej określają jego status jako wieszcza. Słowacki z kolei w większym stopniu opiewany jest w tym gatunku jako poeta, mistrz słowa.

Słowa kluczowe: libretto kantaty, twórczość okolicznościowa, pomnik, kult wieszczów

* Publikacja artykułu dofinansowana przez Uniwersytet Warszawski. 


\section{Wstęp}

Badanie dedykowanej wybitnym artystom twórczości, także tej okolicznościowej, jest znanym nie od dziś sposobem poznania historycznie zmiennych fenomenów, jakimi są recepcja twórczości, budowanie sądów na temat postaci artystów oraz kształtowanie stereotypowych opinii o ich roli w kulturze, a niekiedy i w życiu narodu. Zwłaszcza w przypadku Adama Mickiewicza i Juliusza Słowackiego korpus dostępnych materiałów jest ogromny. Z tego bogactwa wybieram dwa reprezentatywne przykłady - pomniki i zwłaszcza libretta kantat - oraz skupiam się głównie na okresie kulminacyjnym różnych form kultu, przypadającym na przełom wieków, a więc w okolicach setnej rocznicy urodzin obu poetów.

Wskazane formy upamiętniania wieszczów, choć tak różne $\mathrm{z}$ racji użycia odmiennego tworzywa - przestrzennej bryły w pierwszym oraz słowno-muzycznej syntezy w drugim przypadku - w rzeczywistości jednak łączą istotne podobieństwa. Podstawowym $\mathrm{z}$ nich jest wymiar zbiorowy ich funkcjonowania. Zarówno w przypadku wkomponowanego w przestrzeń publiczną pomnika, jak i wykonywanej chóralnie kantaty - właśnie aspekt zbiorowy w decydujący sposób wpływa na to, jaki kształt przybierze dzieło dedykowane poecie. Kantaty okolicznościowe łączyły się z pomnikami również na płaszczyźnie organizacyjnej, jako że ich wykonywanie było jednym z niezbywalnych elementów scenariusza uroczystości upamiętniających wieszczów, w tym odsłaniania kolejnych pomników. Przy tym kantat, o których będzie mowa w dalszych rozważaniach ${ }^{1}$, nie należy mylić $\mathrm{z}$ wielkimi formami wokalnymi muzyki XVIII i XIX wieku komponowanymi przez Johanna Sebastiana Bacha czy Stanisława Moniuszkę. W drugiej połowie wieku dochodzi bowiem do wyraźnego przesunięcia pozycji kantaty z kanonu estetycznego ku funkcjom społecznym. Jak zauważa Irena Poniatowska, w epoce tej

Duża grupa utworów typu kantatowego sytuuje się na granicy twórczości artystycznej i funkcjonalnej, profesjonalnej i amatorskiej. Przewija się w nich tematyka rocznicowa, hołdownicza, patriotyczna i ludowa. Kantata była więc na usługach idei narodowości, upamiętniania historii, ważnych dla kraju i dla społeczeństwa wydarzeń. Jej przesłanie patriotyczno-dydaktyczne dominowało nad ambicjami artystycznymi ${ }^{2}$.

${ }^{1}$ Szerzej charakteryzowałam popularność kantaty okolicznościowej dedykowanej wybitnym jednostkom w studium „Stońcem nam twoja pieśn zajaśniała”. Kantaty ku czci wielkich mężów (a pisarzy zwłaszcza), w: Kantata - oratorium - pasja. Odmiany form literacko-muzycznych $w$ kulturze XVIII i XIX wieku, red. A. Borkowska-Rychlewska, E. Nowicka, Poznań 2019, s. $99-121$.

${ }^{2}$ I. Poniatowska, Twórczość muzyczna $w$ drugiej połowie XIX wieku, w: Historia muzyki polskiej, t. 5: Romantyzm, cz. 2A, red. S. Sutkowski, Warszawa 2010, s. 198. 
Analizując wybrane koncepcje monumentów Mickiewicza i Słowackiego oraz teksty kantat im dedykowanych, można lepiej zrozumieć, w jaki sposób postrzegali obu wieszczów autorzy i odbiorcy twórczości okolicznościowej, czego po wieszczach oczekiwano i czy antagonizm wieszczów wyrażał się również w postawie pochwalnej przyjmowanej wobec obu poetów przez zbiorowość.

\section{U stóp pomników}

Wystarczy nawet pobieżny przegląd materiału, by dostrzec znaczące różnice ilościowe i jakościowe w dziedzinie rzeźby pomnikowej Mickiewicza i Słowackiego. Liczba pomników Adama wielekroć przewyższa liczbę monumentów Juliusza; pomniki tego pierwszego powstawały nie tylko wcześniej (pierwszy z nich ustawiono już w 1859 roku w Poznaniu), ale okazalsze były też ich założenia, a odwołując się do kryteriów fizycznie obiektywnych, są one po prostu większe. Pierwszy polski pomnik Słowackiego powstał dopiero w 1899 roku w wielkopolskim Miłosławiu. Kolekcja Mickiewiczów na cokołach liczyła wówczas już kilka egzemplarzy, w tym najsłynniejsze i symboliczne kompozycje krakowską i warszawską, odsłonięte w roku 1898; dopełniający tej triady pomnik lwowski odsłonięto nieco później, w roku $1904^{3}$.

Zdumiewająca jest różnica rangi miejscowości, w których upamiętniano obu wieszczów. Trudno porównywać urokliwy park angielski i prywatną rezydencję w Miłosławiu z reprezentacyjnymi placami i ulicami dawnych stolic i ośrodków polskiego życia pod trzema zaborami. Pomnikowi Mickiewicze częstokroć stawali się punktami orientującymi topografię miast. Decyzję o prywatnej lokalizacji pierwszego pomnika Słowackiego narzucił czynnik polityczny - zakaz władz pruskich, niechętnych umieszczaniu w przestrzeni publicznej widomych znaków polskiej kultury ${ }^{4}$. Jednak to nie zaborcy zadecydowali o tym, by nie przedstawić Juliusza w wieszczej pozie, którą wypracowano w tym czasie i doprowadzono do perfekcji w monumentach Adama. Trudno przecież nie rozpoznać powtarzającego się - w realizacjach pomnikowych z Przemyśla (1891), Rzeszowa (1892), Tarnopola (1895), Krakowa, Warszawy, Stanisławowa (1898), Złoczowa (1899), a nawet Wieliczki (1903) - charakterystycznego wizerunku pełnofigurowej postaci wieszcza, który znamy z dagerotypów: w wieku dojrzałym, statycznego, w postawie stojącej, z ręką przyciśniętą do serca, niekiedy dzierżącego atrybuty w postaci pióra i księgi, ubranego w surdut, na który zarzucony ma płaszcz z peleryną.

${ }^{3}$ Zdjęcia zdecydowanej większości pomników wymienionych i omówionych w tym tekście można znaleźć w bogato ilustrowanych pozycjach z serii „A to Polska właśnie”: J. Łukasiewicz, Mickiewicz, Wrocław 1996 oraz A. Kowalczykowa, Juliusz Słowacki, Wrocław 2003.

${ }^{4}$ „Kameralne usytuowanie pomnika Słowackiego w prywatnym parku pałacowym w Miłosławiu, to wynik decyzji władz pruskich, które nie pozwoliły wznieść pomnika na miejscu publicznie eksponowanym"; B. Zakrzewski, Z albumu Kościelskich. Pomnik Słowackiego w Miłostawiu, „Rocznik Towarzystwa Literackiego im. Adama Mickiewicza” 1979-1980, R. XIV-XV, s. 146. 
Obok książki i pióra to ten ostatni detal jest najbardziej symbolicznym wyróżnikiem posągowych Adamów, jako że, będąc zarazem elementem realistycznego dziewiętnastowiecznego stroju męskiego, wykorzystywany bywał do uzyskania fantazyjnego efektu opadających fałd nadających odzieniu formę quasi-togi, płaszcza proroków i patriarchów. Zresztą poeta nie zawsze trzyma w ręce książkę, jak to jest w Krakowie, Stanisławowie czy Rzeszowie; równie często jest to zwój - jak w Przemyślu lub Tarnopolu - a więc już konkretnie przymiot proroków starotestamentowych.

Do pewnego stopnia podobieństwo pomnikowych Mickiewiczów jest wynikiem seryjnego ich projektowania przez tych samych artystów ${ }^{5}$. Wśród pomników panowała jednak nieco większa różnorodność, niż mogłoby się wydawać na podstawie przytoczonych przykładów, stawiano bowiem poecie również popiersia lub cokoły z medalionami. A jednak wyraźnie można stwierdzić w tej epoce wykrystalizowanie się ikonicznego wyobrażenia pomnikowego Mickiewicza, a nawet da się prześledzić przyczyny, które po części były za to odpowiedzialne.

Poważniejsze inicjatywy pomnikowe przełomu wieków opierały się na zbiorowym, społecznym wysiłku organizacyjnym i finansowym, częstokroć też projekty wyłaniane były w procedurze konkursowej. Dokumentacja owych konkursów pozwala dziś rekonstruować sposób myślenia o pomniku, nie tylko jako o elemencie estetycznym i komponencie planu urbanistycznego, ale także jako wyrazie koncepcji ideowej, upostaciowaniu zbiorowych sądów na temat upamiętnionej postaci. Dlatego na przykład od uczestników konkursu krakowskiego, w wyniku którego na Rynku Głównym stanął znany dziś pomnik, żądano, by ich projekty utrzymane były w stylu renesansowym, którego regularność i symetria z jednej strony wykazywały pokrewieństwo z upodobaniami estetycznymi pozytywizmu ${ }^{6}$, ale z drugiej zachęcały do wysnuwania daleko posuniętych symbolicznych interpretacji. Karol Matuszewski twierdził na przykład, że „widok linii prostych wiąże się z wrażeniem powagi, energii, surowości, odzywającéj się echem w sercu człowieka i budzącéj w niém uczucie wielkości, majestatyczności lub grozy"7. Linie prostopadła i horyzontalna otwierać z kolei miały na takie wartości jak wieczność, stałość i niezmienność, a w perspektywie estetycznej także wzniosłość. Jak pouczał Matuszewski, „W szeregu istot żyjących, sam tylko człowiek budową ciała przypomina linię prostopadłą. $Z$ wszystkich postaw, jakie on przybrać może,

\footnotetext{
${ }^{5}$ Projekt Tomasza Dykasa został wykorzystany w Przemyślu, Złoczowie i Tarnopolu; pomniki ze Stanisławowa, Tarnowa i Wieliczki łączy autorstwo lwowsko-krakowskiego artysty Tadeusza Błotnickiego.

${ }^{6}$ Cf. D. Kaczmarzyk, Sprawa pomników Adama Mickiewicza, „Ochrona Zabytków” 1956, t. 9, nr. 1-2(32-33), s. 94.

${ }^{7}$ K. Matuszewski, Projekt pomnika Mickiewicza wobec środków i zadań skulptury monumentalnej, „Biblioteka Warszawska” 1883, R. 43, t. 2, s. 265.
} 
jedna tylko postawa stojąca w zupełności odpowiada téj linii i dlatego wyłącznie nadaje się do wyrażenia energii i wzniosłości" ${ }^{8}$. Nie dziw, że wszystkie projekty ukazujące Mickiewicza w jakiejkolwiek innej postawie, poza stojącą, Matuszewski uznawał za chybione i z założenia błędne. Komisja konkursowa generalnie była zgodna w swoich odczuciach artystycznych $\mathrm{z}$ oczekiwaniami recenzenta, skoro $\mathrm{w}$ wymaganiach dla uczestników stały m.in. takie postulaty, by pomnik był „»samoistnym z dominująca postacią Adama Mickiewicza jako narodowego wieszcza «, a »układ pomnika powinien odpowiadać warunkom monumentalności, tak w części figuralnej, jak i architektonicznej «" . Najodleglejszy może od Mickiewiczowskiej sztampy pomnik lwowski również powstał pod dyktat jasno określonych celów: „Pomnik dla Niego ma być kolumną... Tym kształtem czci się zwykle bohaterów, wojowników, albo zaznacza się wielkie fakta dziejowe"10.

Jakie pobudki, w kontekście powyższych przykładów, stały za projektem pierwszego pomnika Słowackiego? Miłosławski monument składa się z wizerunku głowy poety z twarzą poważną, wręcz zasępioną; wyobrażono go w wieku dojrzałym. Rzeźba ustawiona została na czworobocznej kolumnie około czterometrowej wysokości, zaś istotnym uzupełnieniem kompozycji jest pełnofigurowe ujęcie młodej dziewczyny siedzącej u podnóża kolumny i wspierającej się o nią ${ }^{11}$. Koncepcja tej figury, do której pozowała Katarzyna Kościelska, była osobistym pomysłem jej ojca, fundatora monumentu, który w ten sposób chciał oddać hołd tradycji rodzinnej, związanej ze Słowackim nicią prywatnych wspomnień. Matką Kościelskiego była wszak Józefa z Wodzińskich, siostra Marii Wodzińskiej, dawnej muzy poety. Za pośrednictwem obu pań tradycja osobistego kontaktu ze Słowackim, a przy okazji także Chopinem, pozostawała żywa wśród młodszego pokolenia Kościelskich.

Dopełnieniem kompozycji pomnika Słowackiego jest okalająca kolumnę balustrada, przypominająca nieco ławkę i nadająca całości charakter zbliżony

${ }^{8}$ Ibidem, s. 267.

${ }^{9}$ Cit. per W. Okoń, O krakowskim pomniku Adama Mickiewicza raz jeszcze, „Quart” 2006, nr 1, s. 21.

${ }^{10}$ Przemówienie Adama Krechowieckiego na zakończenie działania komitetu jubileuszowego i ogłaszające powstanie komitetu pomnika. Cit. per Rok Mickiewiczowski. Księga pamiątkowa wydana staraniem Kótka Mickiewiczowskiego we Lwowie, cz. 2: Kronika Mickiewiczowska 1898, oprac. A. Bieńkowski, Lwów 1899, s. 41.

${ }^{11}$ Opis prasowy tej kompozycji brzmi: „[...] wysoka kolumna z głowa poety na szczycie. Podobieństwo rysów, doskonale przez artystę jest uchwycone. U stóp kolumny ujrzeliśmy dziewczę urocze, zadumane i zasłuchane niejako w boskie tony lutni wieszcza. Dziewczę siedzi na balustradzie, otaczającéj kolumnę z dwóch stron, a zakończonéj z jednéj strony zniczem złocistym, a z drugiéj strony urną. Całość wykonana z marmuru styryjskiego, szlachetnością głowy poety i postaci dziewczęcia, podniosłe robi wrażenie i prawdziwy zaszczyt przynosi artyście”; Odstonięcie pomnika Juliusza Słowackiego w Miłosławiu, „Dziennik Poznański” 1899, nr 213, s. 2. 
do małej architektury ogrodowej. Porównanie założenia tego pomnika z opartym na zbliżonej koncepcji monumentem Mickiewicza dłuta Antoniego Popiela, odsłoniętym w 1906 roku w Parku Zdrojowym w Krynicy-Zdroju, pozwala snuć domysły o znaczącej różnicy w postrzeganiu obu poetów. Wykonane z brązu popiersie Adama przedstawia jego twarz w ujęciu identycznym jak na pełnopostaciowych statuach, drobiazgowo oddany jest też fragment typowego dla niego stroju - inaczej niż w przypadku miłosławskiego Juliusza, który ukazany jest z klasycznie obnażoną szyją, bez odzieży, a przez to wydaje się wyrwany z kontekstu swojej historyczności. Pod kolumną z Mickiewiczowskim biustem także znajduje się postać dziewczęca, ale jej stojąca postawa i ludowy (jakoby litewski) strój, każący zwyczajowo nazywać ją Zosią, czyni z niej postać uzależnioną od wieszcza: jest jego kreacją, lub ewentualnie alegorią litewskiej muzy, czczącą poetę z modlitewnie złożonymi rękoma. Tymczasem pierwszego pomnikowego Słowackiego ukazano jako poetę intymnego słuchania - prywatnego i jednostkowego kontaktu nawiązywanego z tymi, którzy odczuwają wobec niego nić osobistego przywiązania. Nie przypomina wieszcza ani proroka.

Historia kolejnych pomników Słowackiego to dzieje obiektów planowanych i ostatecznie niezrealizowanych lub koncepcji ziszczonych, ale nie tam, gdzie je pierwotnie lokalizowano, nie w czasie, którego ducha uosabiały, i wreszcie nie tak, jak to zaplanowali ich twórcy. Pomnikowe lekceważenie Słowackiego widać szczególnie mocno w Krakowie, gdzie feta z okazji setnej rocznicy jego urodzin miała zwieńczyć się wielkim pochodem i wmurowaniem kamienia węgielnego pod przyszły pomnik. Do manifestacji nie doszło, kamienia nie wmurowano, pomnik nie powstał, a komitet organizacyjny jubileuszu

Wobec braku poparcia ze strony powołanych do tego czynników, wobec szczupłości grona zajmującego się sprawą pochodu, wobec braku koniecznej jednomyślności w łonie tegoż grona i krótkości czasu, komitet nie chcąc brać na siebie odpowiedzialności za nieudanie się pochodu w rozmiarach, które by odpowiadały chwale Wieszcza, oświadcza niniejszym $\mathrm{z}$ ubolewaniem, że powierzone sobie mandaty składa ${ }^{12}$.

Również we Lwowie, pomimo położenia w 1909 roku kamienia węgielnego, starania o budowę pomnika nie przyniosły rezultatów. Pomnik poznański postawiony został dopiero w 1923 roku w parku (obecnie Park Marcinkowskiego) jako kopia części pomnika z Miłosławia (kolumna z biustem).

Najbardziej może oryginalnym wizerunkiem pomnikowym Juliusza jest monument wrocławski z 1984 roku, wykonany według projektu Wacława Szymanowskiego. Modernistyczny z ducha posąg ukazuje Słowackiego zamyślonego,

${ }^{12}$ Jubileusz Stowackiego, „Naprzód” 1909, nr 288, s. 2; cit. per K. K. Daszyk, Między hołdem uwielbienia a programowym dystansem. O krakowskich obchodach setnej rocznicy urodzin Juliusza Stowackiego, „Zeszyty Naukowe Uniwersytetu Jagiellońskiego. Prace Historyczne” 2010, s. 118. 
wspierającego czoło o dłoń w geście zadumy. Poeta przyobleczony jest w płaszcz, który jednak ani nie fałduje się w Mickiewiczowską togę, ani nawet nie powiewa targany natchnieniem jak na łazienkowskim Chopinie, nieprzypadkowo zresztą podobnym $\mathrm{z}$ twarzy do pomnikowego Słowackiego. Ten sposób jego ujęcia jest dziedzictwem adaptacji, której poddano wariant oryginalny znany z płaskorzeźby w krzemienieckim kościele św. Stanisława. W kompozycji tej Słowacki jest tylko jedną z postaci, góruje nad nim figura rycerza $\mathrm{z}$ opuszczoną przyłbicą i skrzydłami. Podobnie jak Zosia u stóp Mickiewicza w Krynicy-Zdroju, rycerz pełni tu dwojaką funkcję: jest aluzją do dzieł poety i alegorią tworzenia, nadając tej wizji wymiar apoteozy. Powiększony do nadnaturalnych rozmiarów i pozbawiony współtowarzysza, Juliusz osadzony został na stosownym cokole i umieszczony - czy to dzieło przypadku? - na terenach zielonych Wrocławia w pobliżu Promenady Staromiejskiej. Wkomponowany w zieleń, jest to Słowacki niby monumentalny - zważywszy na rozmiary pomnika - a jednak tę wielkość równoważy intymny gest zadumy, w jakiej został ujęty poeta $-\mathrm{z}$ opuszczonym wzrokiem i pogrążony w kontemplacji.

Konsekwentnie rozwijająca się współcześnie sieć pomników Słowackiego pozwala zauważyć znamienną prawidłowość: monumenty stają się coraz większe i nabierają wieszczego rozmachu. Taki charakter ma popiersie z Lublina (Kazimierz Stasz, 1999), wyróżniające się symbolicznym elementem w postaci proroczo rozwianej peleryny płaszcza. Nieudolnie naśladuje Mickiewiczowską pozę wieszcza pomnik rzeszowski (2002), ale pomimo artystycznego fiaska trudno w nim przeoczyć ewidentne nawiązania do sztampowej pozy (ręki na sercu) i prorockiego rekwizytu (zwój). Najbardziej wieszczy charakter ma realizacja warszawska (2001), stojąca na Placu Bankowym monumentalna figura nagiego, muskularnego tytana odzianego w monstrualnych rozmiarów pofałdowany płaszcz, tym razem bez wątpienia należący do wieszcza. Posag ten, przygotowany według przeznaczonego dla Lwowa projektu Edwarda Wittiga, znajduje się, co zdaje się w dwójnasób symboliczne, nie w półprywatnej, parkowej lokalizacji - jak zdecydowana większość pozostałych Słowackich - ale w miejscu posiadającym konotacje biograficzne, w otoczeniu miejskiej architektury, z której monumentalnymi i klasycyzującymi założeniami harmonizuje ciężki i majestatyczny cokól, podniesiony dodatkowo okalającymi go schodami. Jest też Słowacki-tytan następcą na tym miejscu innego pomnika-znaku - wizerunku Feliksa Dzierżyńskiego. Zachęca to do spuentowania zauważalnego i konsekwentnego na przestrzeni stu lat rozwoju twórczości pomnikowej dedykowanej autorowi Kordiana wizją jego symbolicznego zwycięstwa - jako wieszcza i przewodnika (wyzwolonego) narodu. Inaczej niż Mickiewicz, do roli tej jednak Słowacki musiał w oczach swoich rodaków dorosnąć. 


\section{Celebracje i kantaty}

Tezę o stopniowym nadawaniu wizerunkom Słowackiego rangi wieszcza warto zweryfikować i sięgnąć po wiadomości na temat niegdysiejszych obchodów ku jego czci, organizowanych równolegle z pierwszymi inicjatywami pomnikowymi.

Relacjonując w „Przeglądzie Polskim” przebieg krakowskich uroczystości z 1909 roku, Antoni Balicki utyskiwał na zbyt ograny program teatralny (dobrze publiczności krakowskiej znany dramat Złota Czaszka); za bardziej udane uznał górnolotną przemowę Lucjana Rydla oraz Apoteozę pomysłu Ludomira Benedyktowicza, w której „,u stóp biustu [Słowackiego - przyp. M. S.] po całej scenie stały lub siedziały porozrzucane gustownie postacie z utworów Słowackiego, między niemi sam poeta”. Poszczególne figury, budząc się ze snu, „wypowiadały najcharakterystyczniejsze o sobie ustępy", sam zaś poeta recytował Testament $m^{\prime} j^{13}$. Za prawdziwie skandaliczne jednak uznał krytyk milczenie przedstawicieli współczesnego parnasu. „Nikt się do swego nie chciał przyznać Mistrza, nikt nie uczcił jego chwały [...]. Nikt nie zdobył się nawet na wierszyk ad hoc napisany [...]”, a wszak „lepiej było do stóp jego z piosenką pospieszyć”14. Balicki przypomniał niedawne obchody jubileuszowe, na przykład Uniwersytetu Jagiellońskiego, w czasie których „spieszyli śpiewacy ze swoją lutnią”"15. W programach tej uroczystości ${ }^{16}$ nietrudno natrafić na wzmianki o kilku skomponowanych z jej okazji kantatach ${ }^{17}$. Najwyraźniej zatem Balickiemu brakowało w obchodach urodzin Słowackiego tej właśnie formy poetycko-muzycznej pochwały: kantaty.

Trop ów wydaje się tym słuszniejszy, gdy spojrzymy na przebieg ceremonii pomnikowej w Miłosławiu, podczas której odśpiewano specjalnie skomponowaną kantatę do słów Józefa Kościelskiego z muzyką Zygmunta Noskowskiego.

${ }^{13}$ A. E. Balicki, Teatr krakowski, „Przegląd Polski” 1909, R. 44, t. 174, s. 239-240.

${ }^{14}$ Ibidem, s. 240, 241.

${ }^{15}$ Ibidem, s. 241.

${ }^{16}$ Szczegóły programu tej uroczystości i wykonywanych wówczas kantat vide Księga pamiątkowa pięćsetletniego jubileuszu odnowienia Uniwersytetu Jagiellońskiego 1400-1900, Kraków 1901.

${ }^{17}$ Wśród kantat znajdowały się utwory mniej znanych twórców - np. Michała Świerzyńskiego Kantata ku uczczeniu pięćsetletniej rocznicy założenia Uniwersytetu Jagiellońskiego na chóry męzkie z towarzyszeniem orkiestry, muz. M. Świerzyński, sł. J. Świerzyński, [s.l., ca 1900]; inc. „Rozgłosem chwały dziś Alma Mater brzmi” - ale było i dzieło Władysława Żeleńskiego ze słowami Deotymy Gloria tibi Alma Mater. Kantata uroczysta, muz. W. Żeleński, st. [Deotyma], [s.l., ca 1900]; inc. „Boga Rodzico? Dziewico?”. Żeleński był także autorem kantaty z okazji otwarcia budynku Collegium Novum UJ; Kantata uroczysta na chór męski, 2 trąbki, 4 waltornie, 4 puzony $i$ kotty [...] wykonana po raz pierwszy przy uroczystości otwarcia gmachu Wszechnicy Jagiellońskiej dnia 13. czerwca 1887, muz. W. Żeleński, sł. L. German, [Kraków, ca 1887]; inc. „W odwiecznej walce z potęgą ciemności”. Szerzej na ten temat piszę w artykule Topografie kantaty okolicznościowej, [w druku]. 
Kościelski zadbał o to ${ }^{18}$, by uroczystość Słowackiego nie ustępowała najlepszym modelom tego typu gali ${ }^{19}$, wypracowanym - nie inaczej - w czasie jubileuszy Mickiewicza. „Kościelski, nawiązując jakby do niedawnych uroczystości odsłonięcia pomnika Mickiewicza w Warszawie (1898), zaprasza do Miłosławia wielu zasłużonych dla sprawy owego pomnika, przede wszystkim Sienkiewicza (który prowadził pod pomnik Mickiewicza jego córkę - Marię Gorecką), a także dra Karola Benniego" ${ }^{20}$. Śpiewanie kantaty było uznawane za nieodłączny element takiej uroczystości. Jej tekst został opublikowany w relacji prasowej z tego wydarzenia $^{21}$ oraz w antologii poezji ku czci Słowackiego ${ }^{22}$.

Całe libretto Kościelskiego opiera się na metaforyce związanej z pojęciem języka. Koncept ów w pełni zarysowuje już pierwsza zwrotka:

Krew, która do serca zbiega,

To język, narodu skarb.

Bicie, co zeń się rozlega,

To pieśń, stróż, świadek i karb ${ }^{23}$.

Dla autora libretta język polski to czynnik odpowiedzialny za życie organizmu narodowego ${ }^{24}$; aby jednak był w stanie pełnić swoje funkcje, musi mieć stosowny rytm i harmonię. Te zaś, jak wyjaśnia ciąg dalszy wiersza, zawdzięcza czczonemu poecie, który był zdolny nadać narodowej niedoli poetycki wymiar.

Śpiewanie kantat ku czci Słowackiego było wręcz zalecane jako element obchodów rocznicowych masowo organizowanych w 1909 roku. Publikując propozycje scenariuszy okolicznościowych, poznańska „Czytelnia Ludowa” przekonywała, że

Wszystkie prawie nasze miasteczka posiadają towarzystwa śpiewacze, które z pewnością chętnie wykonają kantatę jubileuszową. Odpowiedni, a zarazem łatwy do wykonania i piękny

${ }^{18}$ Starania Kościelskiego miały podłoże także natury osobistej, ponieważ w scenariuszu uroczystości „ujawniają się jakby konkurencyjne ambicje teścia Blocha [Kościelskiego, ojca jego żony, Marii Bloch - przyp. M. S.], najzawziętszego antagonisty na niwie działalności finansowej i społecznej Leopolda Kronenberga, rzecznika uroczystości warszawskiej”; B. Zakrzewski, op. cit., s. 146.

${ }^{19}$ Szczegółowy opis uroczystości zawierają ówczesne gazety, m.in. „Wielkopolanin” 1899, R.17, nr 213, s. 1. Również przywoływana już relacja z „Dziennika Poznańskiego” zawiera informacje o obecnych gościach, których liczba i autorytet służyły podniesieniu rangi wydarzenia. Cf. Odsłonięcie pomnika..., s. 2.

${ }^{20}$ B. Zakrzewski, op. cit., s. 146.

${ }^{21}$ Odstonięcie pomnika..., s. 2.

${ }^{22}$ J. Kościelski, Kantata ku czci Słowackiego, w: Juliusz Słowacki w poezji polskiej (antologia poetycka), red. W. Hahn, Lwów 1910, s. 65.

${ }^{23}$ Ibidem.

${ }^{24}$ Można dopatrywać się w tym chwycie subtelnej aluzji do koncepcji języka-pomnika, wyrażonej w strofach II pieśni Beniowskiego, którą cytuję w podsumowaniu niniejszej rozprawy. 
utwór wydał Gall: Jemu co jak płomienny stup: kantata ku czci Juliusza Słowackiego do słów Stanisława Rossowskiego na chór mieszany z towarzyszeniem fortepianu (Kraków. S. A. Krzyżanowski) $)^{25}$.

Dopuszczano także możliwość wykonania kantat o innej tematyce, byle odpowiednio podniosłych nastrojem, a nawet siegniecie po dzieło tego samego kompozytora zatytułowane Kantata Mickiewiczowska na chór mieszany i męzki $z$ towarzyszeniem fortepianu (na odstonięcie pomnika Adama Mickiewicza we Lwowie) ${ }^{26}$.

Jawne przyzwolenie, ba, nawet zachęta do substytucji Adama przez Juliusza w dedykacji utworu pozwala poczynić kilka ważnych spostrzeżeń. Po pierwsze, że wykonywanie kantat naprawdę traktowano jako obligatoryjny element obchodów „ku czci”; lepiej było dopasować pieśń o innej tematyce, niż uchybić obowiązkowi, zaś awans Słowackiego na pozycję wieszcza wymagał, by fetowano go równie uroczyście jak Mickiewicza. Po drugie, dzieł dedykowanych Słowackiemu było zdecydowanie mniej niż tych ku czci Mickiewicza ${ }^{27}$. Oprócz przywołanych kantat Kościelskiego i Galla istnieją jeszcze poświęcone Słowackiemu dzieła Edmunda Urbanka do tekstu Mikołaja Rybowskiego ${ }^{28}$, Tadeusza Höflingera do słów Zofii Grabińskiej ${ }^{29}$ oraz Mariana Signio z librettem Edmunda Gergowicza ${ }^{30}$. Ponadto w antologii Juliusz Słowacki w poezji polskiej zamieszczono libretta kantat B. Ł. (inc. „Sto lat minęło”) i Leontyny Kosińskiej (inc. „Cześć i chwała Ci” $)^{31}$. W latach dwudziestych z okazji sprowadzenia zwłok poety do Polski skomponował utwór tego gatunku Feliks Rybicki ${ }^{32}$.

Kantaty Mickiewiczowskie powstawały nieco wcześniej, bo już na początku lat dziewięćdziesiątych XIX wieku, a także ich liczba jest dużo wyższa. Oprócz

\footnotetext{
${ }^{25}$ Rok Juliusza Stowackiego, „Czytelnia Ludowa” 1909, R. 4, z. 4, s. 84.

${ }^{26}$ Ibidem, s. 85.

${ }^{27}$ Szerzej omawiam wszystkie kantaty mickiewiczowskie w tekście Adam Mickiewicz i drugie życie kantaty, w: Mickiewiczowskie konteksty, red. M. Cieśla-Korytowska, Kraków 2019.

${ }^{28}$ Kantata ku czci Juliusza Słowackiego, na chór dwugłosowy żeński z tow. fortepianu lub harmonium, muz. E. Urbanek, sł. M. Rybowski, Lwów [1909]; inc. „Chlubo nasza, Wieszczu miły!”.

${ }^{29}$ Kantata ku czci Juliusza Stowackiego, na chór męski z towarzyszeniem harmonium lub fortepianu (ad libitum), muz. T. Höflinger, sł. Z. Grabińska, Lwów [1909]. Informację o tym utworze zawiera W. Hahn, Bibliografia o Juliuszu Stowackim za r. 1909, „Pamiętnik Literacki” 1909, R. 8, z. 1-4, s. 427.

${ }^{30}$ Kantata ku czci Juliusza Stowackiego, na chór mieszany lub dwugłosowy żeński z towarzyszeniem harmonium lub fortepianu, muz. M. Signio, sł. E. Gergowicz, Lwów [ca 1909]; inc. „Sławy Twej pełna Ojczyzna cała".

${ }^{31}$ Juliusz Stowacki w poezji..., s. 233-234, 237-238. Przy wierszu Kosińskiej znajduje się adnotacja o tym, że posiadał on opracowanie muzyczne samej autorki.

${ }^{32}$ Kantata na sprowadzenie zwłok Juliusza Słowackiego, na 3 głosy równe a capp., muz. F. Rybicki, sł. [M. Hemar], Warszawa [1922-1924]; inc. „Na morzu mew girlanda szara”. Dane autora słów podają katalogi BN, na stronie 2 druku widnieje adnotacja „słowa Haema”.
} 
utworów z tekstem i muzyką (Bolesława Dembińskiego ${ }^{33}$, Jana Czubskiego do słów Henryka Stroki ${ }^{34}$, Michała Świerzyńskiego do słów Jana Świerzyńskiego ${ }^{35}$, Feliksa Walczyńskiego do słów Ignacego Nowickiego ${ }^{36}$, Mariana Signio do słów Stanisława Rossowskiego ${ }^{37}$, Edmunda Urbanka do słów Ignacego Nowickiego ${ }^{38}$, Jana Galla do słów Marii Konopnickiej ${ }^{39}$, Stanisława Niewiadomskiego do słów Kazimierza Tetmajera ${ }^{40}$, Zygmunta Noskowskiego do słów Lucjana Rydla ${ }^{41}$ oraz Bolesława Wallek-Walewskiego do słów Rossowskiego ${ }^{42}$ ) dysponujemy jeszcze czterema librettami kantat (Konstantego Marii Górskiego inc. „Od Niemna, od Niemna głos wstaje i płynie”, Lucjana Rydla inc. „Zerwijcie, zerwijcie zasłonę!...”, Jana Kasprowicza inc. „W prastarym grodzie, w stolicy królów” i Karola Łepkowskiego inc. „Pod królewskiemi śpiąca szkarłaty”), które wyróżniono w konkursie krakowskiego komitetu budowy pomnika i opublikowano jako wiersze na łamach „Czasu” w 1893 roku $^{43}$. Część z nich wykorzystana została potem w opracowaniach muzycznych - przez wspomnianego już Noskowskiego oraz Michała Świerzyńskiego ${ }^{44}$.

${ }^{33}$ Cieniom Wieszcza! Kantata na głosy męskie op. 88, muz. B. Dembiński, sł. nieznane, nakładem B. J. Zalewskiego, [Chicago, ca 1925]; inc. „Gdy gaśnie gwiazda na niebie”. Kantata po raz pierwszy wydana została w 1890 r. nakładem J. K. Żupańskiego w Poznaniu.

${ }^{34}$ Kantata wykonana podczas odstonięcia pomnika Adama Mickiewicza w Rzeszowie, dnia 26. Listopada 1892 roku, śpiew na cztery głosy męskie, muz. J. Czubski, sł. H. Stroka, Rzeszów 1892; inc. „Chwałę wieszczowi niech głosi pieśn”.

${ }^{35} \mathrm{Ku}$ uczczeniu setnej rocznicy urodzin Adama Mickiewicza. Kantata $w$ tatwym układzie na solo i chóry unisono z towarzyszeniem fortepianu lub kwartetu smyczkowego, muz. M. Świerzyński, sł. J. Świerzyński, Kraków 1898; inc. „Sto lat już mija”.

${ }^{36}$ Kantata Cieniom Adama Mickiewicza, na głos z towarzyszeniem harmonium, muz. ks. F. Walczyński, sł. I. Nowicki, [s.l., ca 1915]; inc. „W polskiej ziemi głosy płyną”.

${ }^{37}$ Kantata ku czci Adama Mickiewicza, na chór jednogłosowy, dwugłosowy, mięszany lub męski, muz. M. Signio, sł. S. Rossowski, wyd. 2, nakł. Gubrynowicza i Schmidta, Lwów [ca 1898]; inc. „Słońcem nam twoja pieśń zajaśniała”.

${ }^{38} \mathrm{~W}$ setna rocznice urodzin Adama Mickiewicza. Kantata. Układ na 1, 2 lub 3 głosy z towarzyszeniem harmonium lub fortepianu, muz. E. Urbanek, sł. I. Nowicki, [s.l., ca 1898]; inc. „W uroczysty dla nas czas”.

${ }^{39}$ Tekst kantaty na chór męski lub mieszany o inc. „O, cześć! O, cześć i uwielbienie” zawiera Rok Mickiewiczowski. Księga pamiątkowa..., s. 40-41.

${ }^{40}$ Pod Kolumna Wieszcza, op. 25, na chór męski z towarzyszeniem instrumentów dętych lub a capella, muz. S. Niewiadomski, sł. K. Tetmajer, Lwów 1898; inc. „Wieszczu, niechaj nas słucha duch wielki Twój”.

${ }^{41}$ Zadźwięcz pieśni! Kantata na chór męski i orkiestrę dęta, muz. Z. Noskowski, sł. L. Rydel, BJ Rkp. 1937, nr 33; inc. „Zerwijcie, zerwijcie zasłonę!”

${ }^{42}$ Kantata ku czci Adama Mickiewicza, na chór mieszany z towarzyszeniem orkiestry smyczkowej lub bez, muz. B. Wallek-Walewski, sł. S. Rossowski, Kraków 1949; inc. „Słońcem nam Twoja pieśń zajaśniała”. Wydanie zawiera informację, że kantata powstała w 1901 roku i utrzymana była w tonacji D-dur (podniesionej na wygodniejszą do śpiewania F-dur); vide ibidem, s. 15.

${ }^{43}$ Kantaty Mickiewiczowskie, „Czas” 1893, nr 74, s. 2.

${ }^{44}$ Kantata na uroczystość odstonięcia pomnika wieszcza A. Mickiewicza, muz. godło „Niemen” [M. Świerzyński], sł. K. Łepkowski, [s.l., ca 1900]; inc. „Pod królewskiemi śpiąca szkarłaty”. 
Trzecim wreszcie wnioskiem płynącym z faktu, że dopuszczano zamianę Adama na Juliusza, by nie uchybić obowiązkowi wykonywania kantaty „ku czci”, jest to, że libretta tych okolicznościowych utworów charakteryzowały się znacznym stopniem uogólnienia. Cechą wspólną właściwie wszystkich wymienionych wyżej utworów jest ich wzniosły i zarazem sztampowy charakter. Libretta zawierają mnóstwo wspólnych elementów, takich jak tryb rozkazujący, użycie podmiotu zbiorowego, wykrzyknień. Wiele fraz brzmi tak, że z powodzeniem można byłoby je wyjąć z libretta jednej kantaty i umieścić bez szkody dla ogólnego sensu w innym. Niektóre z tekstów zorganizowane są wokół jakiegoś obrazu poetyckiego, jak na przykład przywołana wcześniej metafora języka w kantacie Kościelskiego ku czci Słowackiego, czy też bardzo chętnie wykorzystywana w kantatach dla Mickiewicza topika pomnikowa, odwołująca się do realnych okoliczności, w jakich utwór miał być odśpiewany ${ }^{45}$. Kantaty dla Adama i te dla Juliusza w dużej mierze sa podobne w swojej poetyce, metaforyce, a zwłaszcza rytmie i rymie - te ostatnie są bardzo uproszczone, co jest pochodną muzycznego przeznaczenia do wykonania chóralnego, i to zwykle półprofesjonalnego. $\mathrm{Z}$ tego samego zresztą wynika mało ambitna warstwa muzyczna dzieł ${ }^{46}$.

Możliwe do wskazania zwłaszcza w kantatach ku czci Mickiewicza uogólnienia znaczeniowe prowadzą do wniosku, że faktycznym obiektem pochwały w tych wierszach nie była indywidualność i niepowtarzalność poety, ale rola, w jakiej chcieli go widzieć twórcy, wykonawcy i słuchacze biorący udział w zbiorowych celebracjach. Rolą tą zaś była wyraźnie już sformalizowana w tej epoce funkcja wieszcza, poety-proroka, którego znaczenie rozpatrywać należy w perspektywie społecznej, nie artystycznej.

Czytelny i bezpośredni przekaz zawarty w librettach kantat okolicznościowych pozwala $z$ dużym prawdopodobieństwem rekonstruować ówcześnie rozumiany zakres kompetencji wieszcza. Do owych wieszczych prerogatyw należało: budzenie, podtrzymywanie i jednoczenie narodowego ducha, także w zakresie porozumienia ponadstanowego ${ }^{47}$; dawanie świadectwa idei, której poeta służył swoimi czynami (a zwłaszcza cierpieniem) i twórczością, a która trwa wśród jego czcicieli48;

${ }^{45}$ Cf. M. Sokalska, Adam Mickiewicz i drugie życie..., s. 285-287.

${ }^{46}$ Cf. charakterystyka wybranych kantat okolicznościowych w: M. Sokalska, „Stońcem nam twoja pieśn zajaśniała”....

${ }^{47}$ „Tu bratnią sobie podajmy dłoń [...] Od fal Bałtyku po szczyty gór, / Niech zgodnych głosów zanuci chór” (Kantata wykonana [...] w Rzeszowie..., s. 4); „Dziś uroczysty dzień Cię [Polsko - przyp. M. S.] jednoczy” (Kantata ku czci Adama Mickiewicza, s.1); „Zbratany w jedno lud, / To pieśni Twojej cud" (M. Konopnicka, [Słowa do kantaty ku czci Mickiewicza], s. 40); „W bratniej zgodzie i miłości / Pójdziem pełni wytrwałości / W życia Twego ślad” (W setna rocznicę urodzin..., s. 3).

${ }^{48}$ „Ty kochałeś duszą całą / świętą Matkę Twą. / Tyś ozdobą jej i chwałą. / Pieśń jej niosłeś swą! / [...] Tyś za świętą cierpiał sprawę [...]” (Cieniom Adama Mickiewicza, s. 2-3); „Kto za swój naród cierpiał boleśniej / Niźli Ty [...]?" (Kantata ku czci Adama Mickiewicza, s. 1); 
bycie źródłem pokrzepienia, nadziei i mądrości ${ }^{49}$; bycie strażnikiem, gwarantem i przewodnikiem egzystencji zniewolonego narodu ${ }^{50}$; prorokowanie rychłego odzyskania niepodległości ${ }^{51}$. To właśnie z librett dedykowanych Mickiewiczowi odtworzyć można repertuar wieszczych funkcji, żadna z kantat ku jego czci nie jest bowiem wolna od wizji poety w tej roli. Frekwencja słowa „wieszcz” w tych tekstach jest zaś nierównie wyższa od jego nieśmiałej obecności w kantatach ku czci Słowackiego. Nie bywa nazywany Mickiewicz poetą, zamiast lub obok wieszcza stosowana bywa metonimia „mistrz”; jego twórczość natomiast rozmywa się w wieloznacznym pojęciu „pieśni”. Świadomość tego, że istnieją jeszcze inni poeci aspirujący do rangi wieszcza, skłania autorów librett do podkreślania nadrzędnej pozycji Mickiewicza, jak w kantacie ze słowami Rossowskiego „Czcij Go i kochaj nad wszystkie wieszcze” ${ }^{52}$ lub w kantacie do słów Świerzyńskiego „moc tajemnicza / [...] Polsce wydała na świat Mickiewicza / [...] wieszcza ponad wieszcze" ${ }^{53}$.

W kantatach ku czci Słowackiego jego wieszcze prerogatywy najwyraźniej przedstawił Edmund Gergowicz, w którego tekście spersonifikowana Polska zostaje wezwana - „Wstąp na wyżyny wieszcza naszego, / Co pragnął szczęścia ludu Twojego" 54 , ale zarazem to libretto jest chyba najsłabszym i najbardziej szablonowym spośród wszystkich temu poecie dedykowanych. Nawet w Kantacie na sprowadzenie zwłok Juliusza Stowackiego został on tylko jeden raz nazwany wieszczem: „czeka rozmodlony lud / Na wieszcza u wawelskich bram”55.

„On, / Co wyśpiewał polską sławę, / Czary polskich łąk i pól / I dusz polskich bóle krwawe: / [...] polskiej pieśni Król!” (L. Rydel, Kantata, s. 2); „I wśród hetmanów postawia lud, / Tego, co berło pieśni miał w ręce, / Co huf ku wielkiej przyszłości wiódł” (J. Kasprowicz, Kantata, s. 2).

49 „Pieśnią uczcijmy za pieśń pociechy / Co nam osładza tęsknoty ból” (Ku uczczeniu setnej rocznicy..., s. 3); „Błogosławiona / Pieśń, co sieje w narodzie żywota nasiona” (M. Konopnicka, [Stowa do kantaty ku czci Mickiewicza], s. 41); „Jeśli bogowie na tę ziemię schodzą / To tylko w wieszczów natchnionej postaci. / [...] Wieszcz żyje z nami, bo duch jego pieśni / Ogniem i hartem krzepi w niewoli” (Cieniom wieszcza!, s. 3, 5); „Do niskiej chaty biednego sioła, / Gdzie dola ludu ciemna, / Oświaty z sobą sprowadź anioła” (K. Łepkowski, Kantata, s. 2).

${ }^{50}$ „Starł z narodu wiekową pleśń [...] on rozprószył zwątpienia noc, / Czas prześladowań przetrwać dał moc!” (Kantata wykonana [...] w Rzeszowie..., s. 4); „O Polsko! Szlakiem natchnienia Jego / Niech Twe uczucia i myśli biegą. / W Nim siła władcy, wzrok przewodnika, / Co lepszą przyszłość Tobie odmyka” (Kantata ku czci Adama Mickiewicza, s. 1); „Ogniowym nas słupem wodziła na boje / [...] Nad ziemią zwątpienia, gdzie walą się krzyże / Pieśń czuwa, jest wierną i mężną” (K. M. Górski, Kantata, s. 2); „Mistrzu ślubujem Tobie na pług i miecz, / Że pierwej legniem w grobie, nim krok ustąpim wstecz" (Pod Kolumna Wieszcza, s. 10).

${ }^{51}$ „Mickiewicz woła / Już błysły zorze, wnet upadnie wróg!” (Kantata wykonana [...] w Rzeszowie..., s. 4); „Kto wśród czarnej zawieruchy, / Wśród zamętu klęsk i burz / Wznosi serca, krzepi duchy / I wskazuje blaski zórz” (L. Rydel, Kantata, s. 2); „Jak Anioł Sądu, tak się kołysze / Nad mogiłami Adama pieśń, / Ażeby przerwać cmentarną ciszę, / Życiem rozeprzeć grobową cieśń” (J. Kasprowicz, Kantata, s. 2).

${ }^{52}$ Kantata ku czci Adama Mickiewicza, s. 1.

${ }^{53}$ Ku uczczeniu setnej rocznicy urodzin Adama Mickiewicza, s. 2.

${ }^{54} \mathrm{Ku}$ czci Juliusza Stowackiego, s. 1.

${ }^{55}$ Kantata na sprowadzenie zwłok Juliusza Stowackiego, s. 2. 
Ciekawe zjawisko zauważyć można w libretcie kantaty Leontyny Kosińskiej, która, nie używając nazwy „wieszcz”, określa Słowackiego wielekroć mistrzem i próbuje poetycko definiować jego funkcję: „Tyś był dla nas archaniołem, / Męczennikiem, apostołem" ${ }^{\text {56 }}$. W libretcie Rossowskiego z kolei na określenie zbliżone do wieszcza, ale przecież z nim nietożsame, zaadaptowany został pożyczony od samego Słowackiego Król-Duch. „Król Duch harfę unosi wysoko, / [...] Słuchajcie! pobudka płynie: / Król Duch, gra!" ${ }^{57}$. W kantacie B. Ł. nie ma już nawet takich „wieszczych” sygnałów, za to poeta zostaje wyróżniony spośród innych poetyckich duchów jako „ten srebrnopióry, / Rozanielony, tęczowy”, „Pielgrzym w srebrnej bieli” ${ }^{58}$. W tym samym libretcie znajduje się motyw, który uznać można za znaczeniowy wyróżnik kantat ku czci Słowackiego - analogiczny do wizerunku wieszcza forsowanego w przypadku kantat ku czci Mickiewicza. Oto Słowacki w wizji librecisty ukrywającego się pod inicjałami „B. Ł.” „Z brudnych dróg życia rwie nas do góry / Czarodziejskiemi słowy”,59, tym zaś, co pragnie uzyskać, będzie cud „rozanielenia” zniewolonego narodu budzonego z martwych przez poetę-maga. Jeśli w niektórych kantatach Mickiewiczowskich wskazać można słabe i spłycone, ale jednak rozpoznawalne odniesienia do mesjanizmu poety ${ }^{60}$, to kantaty ku czci Słowackiego znacznie wyraźniej odbijają ideowe i poetyckie okruchy jego koncepcji genezyjskiej. Podmiot zbiorowy cytowanego utworu pyta:

Jakichże, jakich, duchu nasz wielki,

Wysiłków nam potrzeba,

By się w anioła zmienić mógł wszelki

Powszedni ,zjadacz chleba?..."

Z kolei w kantacie Rossowskiego wspólnota zostaje wezwana do aktywnego współudziału w święcie poety i zaangażowania się w jego wizję wędrówki ku doskonaleniu:

Rozweselcie Króla Ducha oko,

Niech naród jak on zapłonie!

${ }^{56}$ L. Kosińska, Słowa do kantaty ułożonej na cześć Juliusza Słowackiego, s. 237.

${ }^{57}$ S. Rossowski, Jemu, co jak ptomienny stup, s. 235.

${ }^{58}$ B. Ł., Stowa do kantaty, s. 233, 234.

${ }^{59}$ Ibidem, s. 233.

${ }^{60}$ Mesjanizm ów wydaje się przede wszystkim ograniczony do oczekiwania nadejścia prorokowanego zbawiciela narodu - w tej roli obsadzany jest Mickiewicz (jako duch, pomnik, idea przyświecająca zniewolonym). Motywem, który zachęca do takich interpretacji, jest przede wszystkim opozycja życia i śmierci oraz obopólne oczekiwanie na zmartwychwstanie: powołanego do dzieła przez naród Mickiewicza i narodu ożywionego mocą wieszcza. Cf. M. Sokalska, Adam Mickiewicz i drugie życie..., s. 288-290.

${ }^{61}$ B. Ł., Stowa do kantaty, s. 234. 
Bo w ogniach droga ku wyżynie,

W ogniach zdobycie nowego dnia ${ }^{62}$.

Tym, co wyróżnia kantaty dla Słowackiego - jako wspólna kilku librettom tendencja - jest zdecydowane waloryzowanie sztuki słowa poety. Mickiewicz zdawkowo bywał w kantatach nazywany „Królem ojczystej pieśni”, jego pieśń „słońcem jaśnieje” (u Rossowskiego), to „pieśni polskiej Król” (u Rydla i dosłownie tak samo u Nowickiego/Walczyńskiego), poeta dzierżył w ręce „,berło pieśni” (u Kasprowicza), jego pieśń dała narodowi „żywota nasiona” (według Konopnickiej), a także zadomowiła się „w sercach ludu” (u Nowickiego/Urbanka), „bucha, radośniej od słońca”, niegdyś „wodziła na boje”, dziś „,zuwa, jest wierną i mężną" (w wizji Górskiego), „splotła wianem dwory i strzechy” (według Świerzyńskiego), jest „Z serca wzięta” i przekazuje „rzewną miłość” dla ojczyzny (u Nowickiego/Walczyńskiego). Wszystkie przytoczone określenia tyczą znowu funkcji pełnionych przez twórczość Mickiewicza, ale nie odnoszą się do artystycznej doniosłości i doskonałości jego dzieł. Tymczasem o Słowackim w kantatach możemy się dowiedzieć na przykład, że

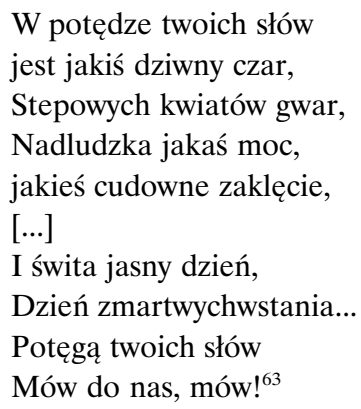

Leontyna Kosińska widzi moc języka poezji Juliusza jeszcze barwniej, posiłkując się metaforyką, która żywo przypomina język samego poety.

Słowa w perły mogłeś zmienić, W tęczę barwną je przemienić, W słońca blaski, w wód kaskady I w bezmierne gwiazd miryady, Lub w straszliwe płacze, jęki, W zgrzyt piekielny, srogie męki ${ }^{64}$.

${ }^{62}$ S. Rossowski, Jemu, co jak płomienny stup, s. 235.

${ }^{63}$ B. Ł., Stowa do kantaty, s. 234.

${ }^{64}$ L. Kosińska, Słowa do kantaty ułożonej na cześć Juliusza Słowackiego, s. 237-238. 


\section{Podsumowanie}

Różnice w postrzeganiu obu twórców - wieszcza Adama i poety Juliusza które wyłaniają się z librett okolicznościowych kantat oraz oglądu ich pomników, trudno uznać za przypadkowe, nawet jeśli wpływ na ostateczny kształt obu grup dzieł miały rozmaite czynniki losowe. Materiał ten jasno dowodzi, że koncepcja równorzędności wieszczów ma wtórny charakter. Awans Słowackiego na pomnikowego wieszcza dokonał się dopiero we współczesnych realizacjach i to właśnie pomniki z przełomu tysiącleci dokumentują ostateczną akceptację przeświadczenia o jego przynależności do panteonu poetów-proroków, przewodników narodowych.

$\mathrm{Z}$ innej strony patrząc, analiza pomników i kantat ukazuje wieszcza Adama już pod koniec XIX wieku jako monumentalnego, ale zreifikowanego tytana, króla pieśniarzy, tyle że pozbawionego indywidualności twórczej, ograniczonego do pełnienia swojej funkcji wobec obciążającego go własnym nieszczęściem i cierpieniem narodu. Wokół poety Juliusza pozostaje przestrzeń zachęcająca do bardziej intymnego kontaktu, a jego rewolucyjne pomysły genezyjskie okazują się udomowione i zaakceptowane. Przede wszystkim jednak Słowacki-czarodziej słowa nie traci - nawet w skłonnej do pustosłowia kantacie okolicznościowej swoistości i odrębności od innych poetów.

Do pewnego stopnia i Mickiewicz, i Słowacki trafnie przewidzieli wskazane wyżej aspekty swojego pośmiertnego kultu. Pierwszy skomentował losy przyszłej sławy żartobliwą strofą Exegi munimentum: „Świeci się pomnik mój nad szklany Puław dach, / Przetrwa Kościuszki grób i Paców w Wilnie gmach" ${ }^{65}$. Przeczuł, że będzie to kult pomnikowy i powszechny, aczkolwiek prowincjonalny („od ponarskich gór i bliźnich Kowna wód [...] aż za Prypeci bród”), charakteryzować się będzie masowością oraz społeczno-politycznym kontekstem („mimo carskich gróźb, na złość strażnikom ceł”), do którego ograniczony zostanie akt lektury.

Inaczej widziałby swój pośmiertny pomnik Słowacki, skoro w pieśni II Beniowskiego dywagował o języku jako jego substytucie:

\section{[...] gdyby się słowa}

Mogły stać nagle indywiduami,

Gdyby Ojczyzną był język i mowa:

Posąg by mój stał, stworzony głoskami,

$\mathrm{Z}$ napisem patri patriae $[\ldots]^{66}$.

${ }^{65}$ A. Mickiewicz, Exegi munimentum aere perennius... Z Horacjusza, w: idem, Dzieła, t. 1: Wiersze, oprac. Cz. Zgorzelski, Warszawa 1993, s. 374-375.

${ }^{66}$ J. Słowacki, Beniowski, w: idem, Dzieła wszystkie, red. J. Kleiner, t. 5, Wrocław 1954, s. 76. 
Pierwszy kpił z masowego kultu, jakby przeczuwając, że stanie się Mickiewiczem uprzedmiotowionym, pomnikiem, okładką bez treści. Drugi zdaje się w większym stopniu ufał w możliwość ocalenia, prawdziwego upamiętnienia przez słowo.

\section{Bibliografia}

Balicki, Antoni Euzebiusz, Teatr krakowski, „Przegląd Polski” 1909, R. 44, t. 174.

Daszyk, Krzysztof Karol, Między hotdem uwielbienia a programowym dystansem. Okrakowskich obchodach setnej rocznicy urodzin Juliusza Słowackiego, „Zeszyty Naukowe Uniwersytetu Jagiellońskiego. Prace Historyczne” 2010, nr 137.

Hahn, Wiktor, Bibliografia o Juliuszu Słowackim za r. 1909, „Pamiętnik Literacki” 1909, R. 8, z.1-4.

Jubileusz Słowackiego, „Naprzód” 1909, nr 288.

Kaczmarzyk, Dariusz, Sprawa pomników Adama Mickiewicza, „Ochrona Zabytków” 1956, t. 9, nr 1-2(32-33).

Kantaty Mickiewiczowskie, „Czas” 1893, nr 74.

Kowalczykowa, Alina, Juliusz Słowacki, Wrocław 2003.

Księga pamiątkowa pięćsetletniego jubileuszu odnowienia Uniwersytetu Jagiellońskiego 1400-1900, Kraków 1901.

Łukasiewicz, Jacek, Mickiewicz, Wrocław 1996.

Matuszewski, Karol, Projekt pomnika Mickiewicza wobec środków i zadań skulptury monumentalnej, „Biblioteka Warszawska” 1883, R. 43, t. 2.

Mickiewicz, Adam, Exegi munimentum aere perennius... Z Horacjusza, w: idem, Dzieła, oprac. Cz. Zgorzelski, t. 1: Wiersze, Warszawa 1993.

Odsłonięcie pomnika Juliusza Słowackiego w Miłosławiu, „Dziennik Poznański” 1899, nr 213.

Okoń, Waldemar, O krakowskim pomniku Adama Mickiewicza raz jeszcze, „Quart” 2006, nr 1.

Poniatowska, Irena, Twórczość muzyczna $w$ drugiej połowie XIX wieku, w: Historia muzyki polskiej, t. 5: Romantyzm, cz. 2A, red. S. Sutkowski, Warszawa 2010.

Rok Juliusza Stowackiego, „Czytelnia Ludowa” 1909, R. 4, z. 4.

Rok Mickiewiczowski. Księga pamiątkowa wydana staraniem Kótka Mickiewiczowskiego we Lwowie, cz. 2: Kronika Mickiewiczowska 1898, oprac. A. Bieńkowski, Lwów 1899.

Słowacki, Juliusz, Beniowski, w: idem, Dzieła wszystkie, red. J. Kleiner, t. 5, Wrocław 1954.

Sokalska, Małgorzata, „Słońcem nam twoja pieśń zajaśniała”. Kantaty ku czci wielkich mężów (a pisarzy zwłaszcza), w: Kantata - oratorium - pasja. Odmiany form literacko-muzycznych w kulturze XVIII i XIX wieku, red. A. Borkowska-Rychlewska, E. Nowicka, Poznań 2019.

Sokalska, Małgorzata, Adam Mickiewicz i drugie życie kantaty, w: Mickiewiczowskie konteksty, red. M. Cieśla-Korytowska, Kraków 2019.

Sokalska, Małgorzata, Topografie kantaty okolicznościowej, [w druku]. 
„Wielkopolanin” 1899, R. 17, nr 213.

Zakrzewski, Bogdan, Z albumu Kościelskich. Pomnik Słowackiego w Miłosławiu, „Rocznik Towarzystwa Literackiego im. Adama Mickiewicza” 1979-1980, R. XIV-XV.

\section{Bibliografia - kantaty}

B. Ł., Słowa do kantaty, w: Juliusz Słowacki w poezji polskiej (antologia poetycka), red. W. Hahn, Lwów 1910.

Cieniom Wieszcza! Kantata na głosy męskie op. 88, muz. B. Dembiński, sł. nieznane, [Chicago, ca 1925]; inc. „Gdy gaśnie gwiazda na niebie”.

Gloria tibi Alma Mater. Kantata uroczysta, muz. W. Żeleński, sł. [Deotyma], [s.l., ca 1900]; inc. „Boga Rodzico? Dziewico?”.

Górski, Konstanty Maria, Kantata, „Czas” 1893, nr 74.

Kantata Cieniom Adama Mickiewicza, na głos z towarzyszeniem harmonium, muz. ks. F. Walczyński, sł. I. Nowicki, [s.l., ca 1915]; inc. „W polskiej ziemi głosy płyną”.

Kantata ku czci Adama Mickiewicza, na chór jednogłosowy, dwugłosowy, mięszany lub męski, muz. M. Signio, sł. S. Rossowski, wyd. 2, nakł. Gubrynowicza i Schmidta, Lwów [ca 1898]; inc. „Słońcem nam twoja pieśń zajaśniała”.

Kantata ku czci Adama Mickiewicza, na chór mieszany z towarzyszeniem orkiestry smyczkowej lub bez, muz. B. Wallek-Walewski, sł. S. Rossowski, Kraków 1949; inc. „Słońcem nam Twoja pieśń zajaśniała”.

Kantata ku czci Juliusza Słowackiego, na chór dwugłosowy żeński z tow. fortepianu lub harmonium, muz. E. Urbanek, sł. M. Rybowski, Lwów [1909]; inc. „Chlubo nasza, Wieszczu miły!".

Kantata ku czci Juliusza Słowackiego, na chór męski z towarzyszeniem harmonium lub fortepianu (ad libitum), muz. T. Höflinger, sł. Z. Grabińska, Lwów [1909].

Kantata ku czci Juliusza Słowackiego, na chór mieszany lub dwugłosowy żeński z towarzyszeniem harmonium lub fortepianu, muz. M. Signio, sł. E. Gergowicz, Lwów [ca 1909]; inc. „Sławy Twej pełna Ojczyzna cała”.

Kantata ku uczczeniu pięćsetletniej rocznicy założenia Uniwersytetu Jagiellońskiego na chóry męzkie z towarzyszeniem orkiestry, muz. M. Świerzyński, sł. J. Świerzyński, [s.l., ca 1900]; inc. „Rozgłosem chwały dziś Alma Mater brzmi”.

Kantata na sprowadzenie zwłok Juliusza Słowackiego, na 3 głosy równe a capp., muz. F. Rybicki, sł. [M. Hemar], Warszawa [1922-1924]; inc. „Na morzu mew girlanda szara”.

Kantata na uroczystość odsłonięcia pomnika wieszcza A. Mickiewicza, muz. godło „Niemen” [M. Świerzyński], sł. K. Łepkowski, [s.1., ca 1900]; inc. „Pod królewskiemi śpiąca szkarłaty".

Kantata uroczysta na chór męski, 2 trąbki, 4 waltornie, 4 puzony i kotty [...] wykonana po raz pierwszy przy uroczystości otwarcia gmachu Wszechnicy Jagiellońskiej dnia 13. czerwca 1887, muz. W. Żeleński, sł. L. German, [Kraków, ca 1887]; inc. „W odwiecznej walce $\mathrm{z}$ potęgą ciemności”.

Kantata wykonana podczas odsłonięcia pomnika Adama Mickiewicza w Rzeszowie, dnia 26. Listopada 1892 roku, śpiew na cztery głosy męskie, muz. J. Czubski, sł. H. Stroka, Rzeszów 1892; inc. „Chwałę wieszczowi niech głosi pieśń”. 
Kasprowicz, Jan, Kantata, „Czas” 1893, nr 74.

Konopnicka, Maria, [Stowa do kantaty ku czci Mickiewicza], w: Rok Mickiewiczowski. Księa pamiątkowa wydana staraniem Kółka Mickiewiczowskiego we Lwowie, cz. 2: Kronika Mickiewiczowska 1898, oprac. A. Bieńkowski, Lwów 1899.

Kosińska, Leontyna, Słowa do kantaty ułożonej na cześć Juliusza Słowackiego, w: Juliusz Słowacki w poezji polskiej (antologia poetycka), red. W. Hahn, Lwów 1910.

Kościelski, Józef, Kantata ku czci Słowackiego, w: Juliusz Słowacki w poezji polskiej (antologia poetycka), red. W. Hahn, Lwów 1910.

Ku uczczeniu setnej rocznicy urodzin Adama Mickiewicza. Kantata w tatwym układzie na solo $i$ chóry unisono z towarzyszeniem fortepianu lub kwartetu smyczkowego, muz. M. Świerzyński, sł. J. Świerzyński, Kraków 1898; inc. „Sto lat już mija”.

Łepkowski, Karol, Kantata, „Czas” 1893, nr 74.

Pod Kolumna Wieszcza, op. 25, na chór męski z towarzyszeniem instrumentów dętych lub a capella, muz. S. Niewiadomski, sł. K. Tetmajer, Lwów 1898; inc. „Wieszczu, niechaj nas słucha duch wielki Twój”.

Rydel, Lucjan, Kantata, „Czas” 1893, nr 74.

W setna rocznicę urodzin Adama Mickiewicza. Kantata. Układ na 1, 2 lub 3 głosy z towarzyszeniem harmonium lub fortepianu, muz. E. Urbanek, sł. I. Nowicki, [s.l., ca 1898]; inc. „W uroczysty dla nas czas”.

Zadźwięcz pieśni! Kantata na chór męski i orkiestrę dęta, muz. Z. Noskowski, sł. L. Rydel, BJ Rkp. 1937, nr 33; inc. „Zerwijcie, zerwijcie zasłonę!”.

MaŁgOrZATA SoKAlSKA, dr hab., adiunkt w Katedrze Komparatystyki Literackiej Wydziału Polonistyki Uniwersytetu Jagiellońskiego; autorka książek: O inspiracjach operowych w „Irydionie” Zygmunta Krasińskiego (2004), Opera a dramat romantyczny. Mickiewicz - Krasiński - Słowacki (2009), Wagnerowska mozaika. Wagner $i$ wagneryzm $w$ kulturze (2018); redaktorka monografii naukowych: Wokót Krasińskiego (2012), Opera w kulturze (2016); specjalizuje się w badaniu związków literatury i muzyki, gatunków synkretycznych - opery, pieśni - a także biografii kompozytorów i recepcji ich postaci oraz muzyki w tekstach kultury. 